\title{
High cadmium concentrations in Jurassic limestone as the cause for elevated cadmium levels in deriving soils: a case study in Lower Burgundy, France
}

\author{
Claire M. C. Rambeau • Denis Baize · Nicolas Saby • \\ Virginie Matera $\cdot$ Thierry Adatte $\cdot$ Karl B. Föllmi
}

Received: 9 May 2009/Accepted: 11 January 2010/Published online: 16 February 2010

(C) Springer-Verlag 2010

\begin{abstract}
Cadmium (Cd) is a highly toxic element and its presence in the environment needs to be closely monitored. Recent systematic surveys in French soils have revealed the existence of areas in eastern and central France, which show systematically high cadmium concentrations. It has been suggested that at least part of these anomalous levels are of natural origin. For the Lower Burgundy area in particular, a direct heritage from the Jurassic limestone bedrock is highly suspected. This potential relationship has been studied in several localities around Avallon and this study reports new evidence for a direct link between anomalously elevated cadmium contents of Bajocian and Oxfordian limestone and high cadmium concentrations in deriving soils. Soils in this area show cadmium concentrations generally above the average national population values, with contents frequently higher than the 'upper whisker' value of $0.8 \mu \mathrm{g} \mathrm{g}^{-1}$ determined by statistical evaluation. In parallel, limestone rocks studied in the same
\end{abstract}

C. M. C. Rambeau $(\bowtie) \cdot$ V. Matera · T. Adatte · K. B. Föllmi Institut de Géologie, Université de Neuchâtel, rue Emile-Argand 11, 2007 Neuchâtel, Switzerland

e-mail: rambeauc@googlemail.com

Present Address:

C. M. C. Rambeau

The University of Reading, Whiteknights,

Reading RG6 6AB, UK

D. Baize $\cdot$ N. Saby

Science du Sol UR 0272, Institut National de la Recherche Agronomique, Av. de la Pomme de Pin, CS 40001,

45075 Orléans Cedex 2, France

Present Address:

T. Adatte · K. B. Föllmi

Institut de Géologie et Paléontologie, Université de Lausanne,

Anthropole, 1015 Lausanne, Switzerland area exhibit cadmium concentrations frequently exceeding the mean value of $0.030-0.065 \mu \mathrm{g} \mathrm{g}^{-1}$ previously given for similar rocks by one order of magnitude with a maximum of $2.6 \mu \mathrm{g} \mathrm{g}^{-1}$. Mean ratios between the cadmium concentrations of limestone bedrock and deriving soils $\left(\mathrm{Cd}_{\text {soil }} / \mathrm{Cd}_{\text {rock }}\right)$, calculated for different areas, range from 4.6 to 5.7. Calculations based on the analyses of both soils from a restricted area and fragments of bedrock sampled in the immediate vicinity of high-concentration soils are around 5.5-5.7. $\mathrm{Cd}_{\text {soil }} / \mathrm{Cd}_{\text {rock }}$ is useful in determining the potential of soils in Lower Burgundy to reflect and exacerbate the high concentrations of cadmium present in parent bedrocks.

Keywords Cadmium - Soils · Burgundy · Jurassic . Limestone

\section{Introduction}

In the last few decades, monitoring of trace elements in soils has become a subject of increasing concern. Our consciousness with regard to possible health problems linked with high metal (or more generally, trace element) contents within the soil systems has grown. As a consequence, systematic studies have been conducted across France to study the trace element contents of soils, focusing especially on elements that have a noxious effect on human health (mercury, lead, cadmium and arsenic; ASPITET program, Baize 1997, 2000; and ADEME program, Baize et al. 2006). There has been an increasing concern to monitor soil quality, which is reflected in a series of official documents (e.g., Décret No. 97.1133 du 8 Décembre 1997 and Arrêté du 8 Janvier 1998 for France; OSol 1998 for Switzerland). In parallel, to acknowledge soil natural variability, soil 
scientists have introduced and used the notion of 'pedogeochemical context' (e.g., Baize 1997; Baize and Sterckeman 2001; Palumbo et al. 2000; Colinet et al. 2004). Natural pedo-geochemical backgrounds have been defined as the concentration of a specific chemical element in a soil, resulting from natural geological and pedological processes in a given area, and independent of anthropogenic influence (Baize 1997). It depends both on the initial composition of the parent material (bedrock) and of further geochemical differentiation (vertical and lateral) resulting from soilforming processes such as weathering, lixiviation, translocation, redistribution and concentration of the various soil components.

In spite of rather low flux rates and moderate concentrations in the soil environmental compartment, cadmium (Cd) is on top of the list of potentially toxic metals and therefore needs to be closely monitored. Several areas in central and eastern France show anomalously high cadmium concentrations in soils that seem independent of human activity, in particular in the Burgundy and French Jura regions (Baize 1997; Baize and Paquereau 1997, Baize et al. 1999; Prudente 1999; Prudente et al. 2002). These high concentrations continue in the adjacent Swiss Jura (e.g., Atteia et al. 1994, 1995; Benitez-Vasquez 1999; Baize and Sterckeman 2001; Dubois et al. 2002). Recent studies conducted in the French and Swiss Jura area (e.g., Benitez-Vasquez 1999; Prudente 1999; Baize and Sterckeman 2001; Dubois et al. 2002; Prudente et al. 2002; Quezada-Hinojosa et al. 2009) have shown that anomalously high cadmium contents in soils are due to unexpectedly high cadmium concentrations in the associated bedrocks, which consist of limestone of specific Jurassic ages. The elevated cadmium values displayed by these bedrocks are quite surprising, since following previous surveys of cadmium concentrations in major rock types, carbonate rocks are supposed to be depleted in cadmium relative to the average continental crust, with a mean cadmium concentration of around $0.030-0.065 \mu \mathrm{g} \mathrm{g}^{-1}$ (Kabata-Pendias and Pendias 1992; Alloway 1995; Tuchschmid 1995). However, investigations concerning cadmium contents in Jurassic carbonates in western and southern Europe (Rambeau 2006) have highlighted a general increase of cadmium contents in calcareous rocks for both the Bajocian and Oxfordian periods of the Jurassic, which renders these rocks possible sources for high cadmium concentrations in deriving soils.

To identify regions in France that show anomalously high trace element concentrations in soils (whatever their specific causes), several pedological studies have used the concept of 'outliers' (e.g., Baize and Paquereau 1997; Baize et al. 1999). These 'outliers' (or more accurately, 'upper outliers') are defined by statistical means as values showing significantly higher concentrations than the total population on a national scale, following the definition of Tukey 1977 (see "Materials and methods" for a detailed statistical definition). While a statistical determination of outliers may be used in other contexts to identify potential measurement errors in a population, outlier values were used in these studies to differentiate real, reproducible, measurements significantly distant from the analyses of the rest of a given population (McGrath and Loveland 1992). We followed the same approach in this study and defined cadmium concentration outliers in French soils with reference to the national population described in the following paragraph.

The results of the national survey ADEME/INRA (10,634 soil analyses irregularly distributed across the French territory; Baize et al. 2006) allow for the production of maps showing the distribution of cadmium in France. Previously published maps with regard to $\mathrm{Cd}$ distribution were based on the number of upper outliers or on median values (Baize et al. 1999). A map based on the ratio number of outliers/total number of available sample measurements (NO/NS), per agricultural area (AA), which highlights the zones showing anomalously high cadmium contents, is presented here (Fig. 1). The definition of AA dates back to the subdivision of the French territory into small agricultural areas (SAAs), the result of an intradepartmental cutting carried out by geographers. The SAAs constituted groupings of communes into homogeneous zones with regard to soil and climate conditions, as well as to the dominant vocation of farms. This zoning was carried out at the request of authorities in the 1950s to be used as a territorial framework for the production of many agricultural statistics. Adjacent SAAs of close characteristics were gathered in the same AA at a national level.

Seventeen AAs in France present a ratio NO/NS higher than $15 \%$. At least eight of them (Table 1) correspond to zones where Jurassic calcareous rocks represent the dominant or (almost) exclusive lithology (for the 'Saintonge agricole' and 'Aunis' AAs, Cretaceous limestone also form part of the bedrock). The Jura Mountains comprise two of the most anomalous AAs (1-3, Table 1, Fig. 1) with regard to cadmium. This area has been the framework of specific studies (Dubois et al. 2002; Prudente 1999; Prudente et al. 2002; Quezada-Hinojosa et al. 2009), which concluded that most of the cadmium found in soils, both in forest and agricultural contexts, is of geogenic origin.

The Burgundy region also holds an important anomalous zone regarding cadmium concentrations, distributed over two AAs (2-4, Table 1, Fig. 1). Here, a link between high cadmium concentration in the Jurassic limestone and related elevated values in soils is also highly suspected (Baize et al. 1999; Baize and Roddier 2002). The results of specific investigations concerning cadmium contents in Jurassic limestone for selected localities of Lower Burgundy, which 
Fig. 1 Ratio number of outliers per number of available sample measurements (NO/NS) for cadmium concentrations, in percentages per agricultural area (AA). Only the AAs for which more than 21 analyses were available were taken into account. Outlier values are determined by a statistical analysis of the total national population of 10,634 soil measurements and correspond to values above $0.8 \mu \mathrm{g} \mathrm{g}^{-1} 1$ Plateaux Moyens du Jura; 2 Bourgogne nivernaise; 3

Plateaux Supérieurs du Jura; 4 Plateaux de Basse Bourgogne; 5 Saintonge viticole; 6 Vignoble du Barrois; 7 Saintonge agricole; 8 Aunis; 9 AutunoisAuxois; 10 Pevèle; 11 Haut Limousin

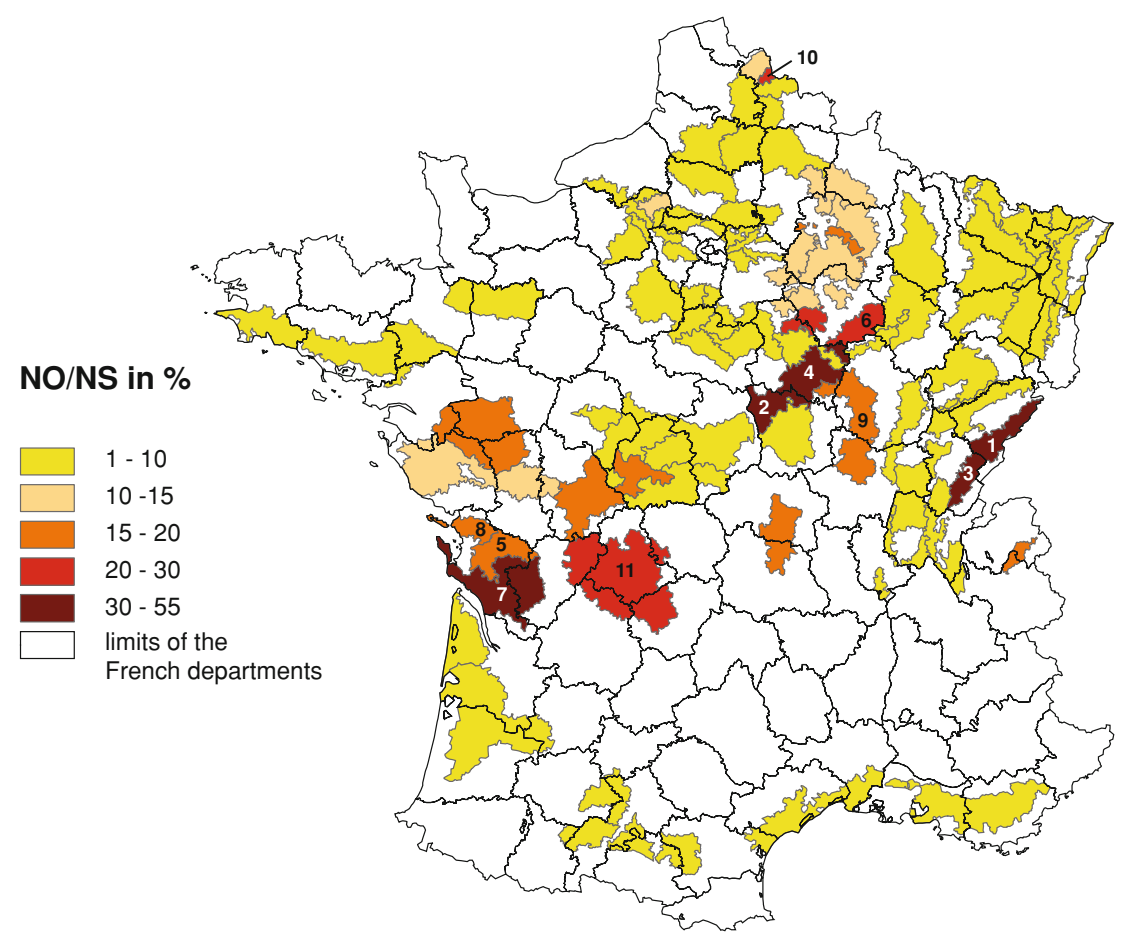

Table 1 Cadmium NO/NS ratios of eight anomalous agricultural areas (France) and relationships with cadmium anomalies in the Jurassic calcareous bedrock

\begin{tabular}{lll}
\hline AA name & NO/NS ratio (\%) & Relationship \\
\cline { 2 - 3 } & & Argued \\
\hline Plateaux Moyens du Jura_Jura Medium Plateaus (1) & 55 & X (a) \\
Bourgogne nivernaise_Burgundy in the vicinity of Nevers (2) & 54 & X (b) \\
Plateaux Supérieurs du Jura_Jura Higher Plateaus (3) & 44 & X (a) \\
Plateaux de Bourgogne-Burgundy Plateaus (4) & 32 & X (b) \\
Saintonge viticole_Vineyard of Saintonge (5) & 31 & X \\
Vignoble du Barrois-Barrois Vineyard (6) & 23 & X \\
Saintonge agricole-Agricultural Saintonge (7) & 15 & X \\
Aunis (8) & 15 & X \\
\hline
\end{tabular}

The numbers following AA names refer to corresponding locations on Fig. 1

Outlier values are determined by a statistical analysis of the total national population of 10,634 soil measurements and correspond to values above $0.8 \mathrm{mg} \mathrm{kg}^{-1}$

$A A$ agricultural area

NO/NS number of outliers/total number of available sample measurements. Data from the ADEME/INRA program (Baize et al. 2006)

(a) Prudente et al. (2002)

(b) This study

present anomalously high cadmium concentrations in soils, are presented in this paper. The goal of this study was to investigate the impact of limestone weathering on high cadmium concentrations in soils related to this geographical zone. Limestone sampling was carried out in selected localities of established cadmium anomalies in soils. Special attention was paid to two sites: (1) the Frétoy Forest and adjacent fields, where all analyzed soils, which developed from a reef complex of Late Oxfordian age, showed outlying cadmium contents; and (2) the Blacy area, where the soils containing high cadmium concentrations appeared to be related to the weathering of crinoidal limestone of the Bajocian in age. Limestone rocks in the immediate vicinity of soils particularly rich in cadmium (rock fragments inside 
the soil and/or underlying bedrock) were sampled and analyzed. In addition, a stratigraphic section outcropping a few kilometers from the investigated localities was studied in both cases to gain information on the general evolution of cadmium contents during the Late Oxfordian and the Bajocian (sections of Le Saussois and of Lucy-le-Bois, respectively).

\section{Materials and methods}

\section{Soil samples}

The results of two national surveys on trace element contents in French soils (total of 262 samples; Fig. 2) were included in this study:

- 'Collecte nationale ADEME/INRA' (Baize et al. 2006; see also Baize et al. 1999), which considered ploughed topsoils of agricultural lands selected to be spread with urban sewage sludge.

- 'ASPITET' program (Baize 1997; Baize et al. 1999): Lower Burgundy part, which considered surface and deep horizons of both agricultural and forest soils.

Samples related to the specific geographical zones that were studied for cadmium contents in the corresponding bedrock have been listed in Table 2. Associated sample localities are plotted in Fig. 2: Frétoy Forest (1); Coulanges zone (2); Clamecy fields (3); Précy-le-Sec zone (4); Blacy area and laterally equivalent soils (7, 9 and 12); Pousseau (11).
Rock samples

All sample localities are reported in Fig. 2. $N$ corresponds to the number of samples related to each locality.

\section{Oxfordian limestone}

Samples of the limestone bedrock (Oxfordian Mailly-leChâteau reef complex; $N=21$ ) were taken for analysis along a NW-SE transect inside the Frétoy Forest, situated between the villages of Courson-les-Carrières (north) and Coulanges-sur-Yonne (south), between the junction point of the road D.130 and the Grange Cathelin Line and the junction point of the road D.39 and the Lac Marry Line (Fig. 2, point 1).

Six small sections, each a few meters thick, were investigated. In each section, the limestone bedrock just underneath the soils was sampled and, wherever possible, additional samples were taken at 20-40 cm intervals down the section.

Rock fragments were additionally sampled in the Clamecy fields ( $N=4$; Fig. 2, point 3) and in the Précy-leSec zone (Cravant limestone; $N=3$; Fig. 2, point 4), which both represent areas affected by high $\mathrm{Cd}$ contents in the corresponding soils.

A stratigraphic section corresponding to the Oxfordian Mailly-le-Château reef complex was studied at the Le Saussois cliff, which outcrops $5,500 \mathrm{~m}$ southwest of the village of Mailly-la-Ville, in the vicinity of the Merry-surYonne village (Fig. 2, point 5). The uppermost $25 \mathrm{~m}$ of the section were sampled $(N=10)$. A complementary section
Fig. 2 Map of pedo-geological units and cadmium concentrations in soils for the Lower Burgundy. Cadmium analyses in soils from ADEME/ INRA and ASPITET programs. Cartographic data from Baize 1993 and Baize 1996. Pedogeological categories are described in the text. Numbers refer to places cited in the text and in Table 2, which have been the locality of detailed studies concerning cadmium concentrations in soils and/or rocks

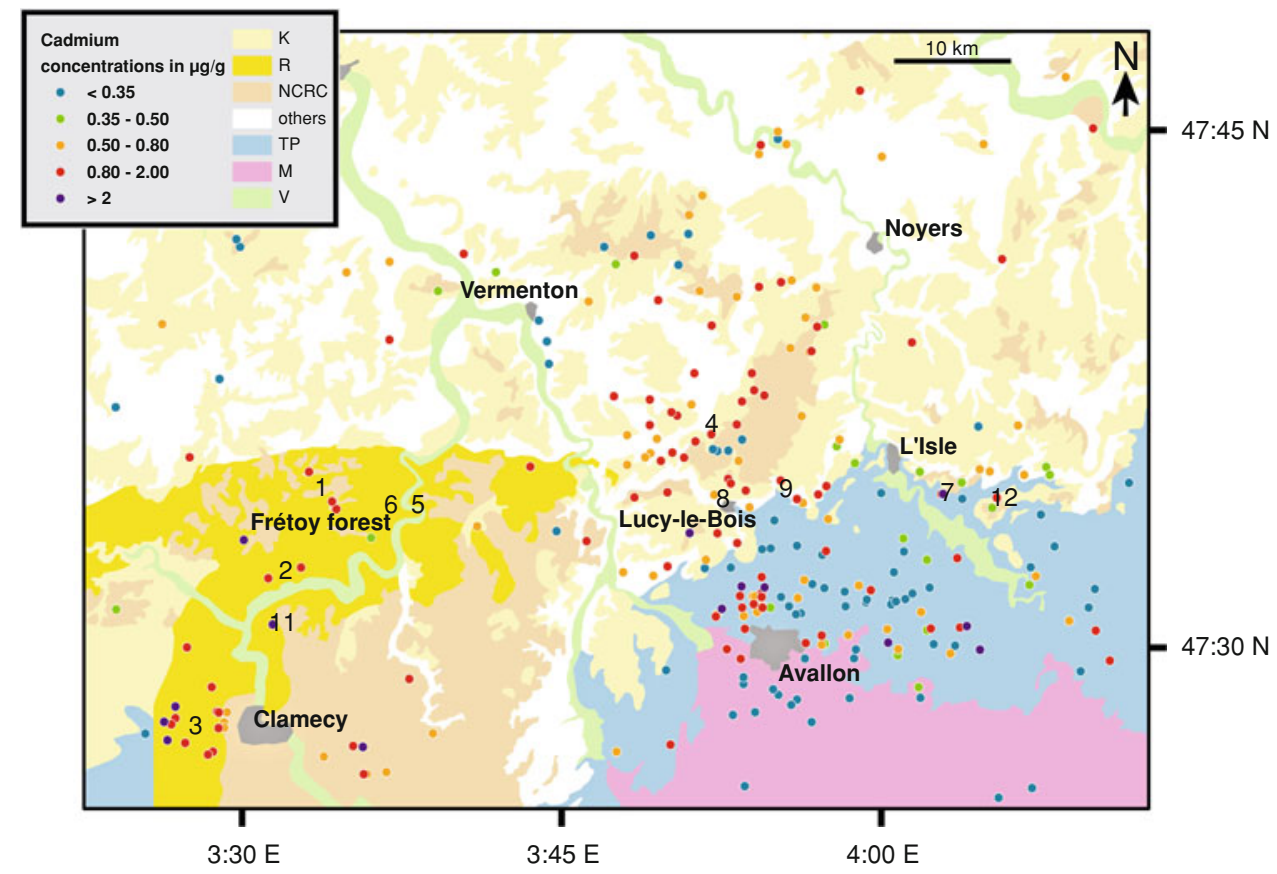


Table 2 Cadmium concentrations in soils and carbonate rocks in Lower Burgundy, related to the Mailly-le-Château Oxfordian reef and lateral equivalents

\begin{tabular}{|c|c|c|c|c|c|c|c|}
\hline \multicolumn{5}{|l|}{ Soils } & \multicolumn{3}{|c|}{ Carbonate rocks } \\
\hline Sample & $\begin{array}{l}\text { Sampling } \\
\text { depth }(\mathrm{cm})\end{array}$ & Forest & Fields & $\begin{array}{l}\text { Cadmium } \\
\text { concentration } \\
(\mu \mathrm{g} / \mathrm{g})\end{array}$ & Sample & $\begin{array}{l}\text { Sampling } \\
\text { depth }(\mathrm{cm})\end{array}$ & $\begin{array}{l}\text { Cadmium } \\
\text { concentration } \\
(\mu \mathrm{g} / \mathrm{g})\end{array}$ \\
\hline
\end{tabular}

Frétoy Forest (top of Mailly-le-Château reef)

$\begin{array}{lll}\text { Frét1 (1) } & 0-15 & \mathrm{X} \\ \text { Mais (1) } & 10-20 & \mathrm{X} \\ \text { Rabo (1) } & 20-35 & \mathrm{X} \\ \text { Frét2 (1) } & 45-75 & \mathrm{X} \\ & \begin{array}{c}\text { Soils associated with other outcrops } \\ \text { of the Mailly-le-Château reef }\end{array}\end{array}$

$\begin{array}{ll}\text { Coul (2) } & 0-5 \\ \text { Cimt (2) } & 0-10 \\ \text { Crai (2) } & 0-15 \\ \text { Cla1 (3) } & 0 \\ \text { Cla2 (3) } & 0 \\ \text { Cla3 (3) } & 0 \\ \text { Cla4 (3) } & 0 \\ \text { Cla5 (3) } & 0 \\ \text { Cla6 (3) } & 0 \\ \text { Cla7 (3) } & 0 \\ \text { Cla8 (3) } & 0 \\ \text { Cla9 (3) } & 0 \\ \text { Cla10 (3) } & 0 \\ \text { Cla11 (3) } & 0 \\ \text { Cla12 (3) } & 0 \\ \text { Cla13 (3) } & 0 \\ \text { Cla14 (3) } & 0 \\ \text { Cla15 (3) } & 0 \\ \text { Cla16 (3) } & 0 \\ \text { Cla18 (3) } & 0 \\ \text { Cla19 (3) } & 0 \\ \text { Cla20 (3) } & 0 \\ \text { Cla21 (3) } & 0 \\ \text { Cla22 (3) } & 0 \\ \text { Cla23 (3) } & 0 \\ \text { Oisy (3) } & 0-5\end{array}$

Oisy (3) $\quad 0-5$

Varv (3) 0-20

Pous (11) 0-15

Soils associated with lateral equivalents of the Mailly-le-Château reef

$\begin{array}{ll}\text { Précy (4) } & 0-20 \\ \text { Suchy (4) } & 0-20 \\ \text { Rompi (4) } & 0-15\end{array}$

\begin{tabular}{|c|c|c|c|c|}
\hline & \multicolumn{4}{|c|}{ Frétoy Forest } \\
\hline & 1.29 & FM1 (1) & 5 & 0.19 \\
\hline & 1.2 & FM2 (1) & 5 & 0.20 \\
\hline & 1.24 & FM3 (1) & 35 & 0.20 \\
\hline & 2.59 & FM4 (1) & 35 & 0.21 \\
\hline & & FM5 (1) & 65 & 0.12 \\
\hline & & FM6 (1) & 80 & 0.15 \\
\hline & 2.14 & FR1 (1) & 5 & 0.20 \\
\hline & 1.26 & FR2 (1) & 30 & 0.23 \\
\hline & 1.13 & RA1 (1) & 5 & 0.27 \\
\hline $\mathrm{X}$ & 1.56 & RA2 (1) & 35 & 0.29 \\
\hline$X$ & 1.56 & RA3 (1) & 75 & 0.34 \\
\hline $\mathrm{X}$ & 0.94 & CH1 (1) & 5 & 0.37 \\
\hline $\mathrm{X}$ & 2.78 & $\mathrm{CH} 2$ (1) & 35 & 0.55 \\
\hline$X$ & 2.86 & CH3 (1) & 65 & 0.29 \\
\hline $\mathrm{X}$ & 1.42 & AN1 (1) & 30 & 0.34 \\
\hline $\mathrm{X}$ & 2.3 & AN2 (1) & 60 & 0.31 \\
\hline $\mathrm{X}$ & 1.25 & AN3 (1) & 90 & 0.36 \\
\hline $\mathrm{X}$ & 0.99 & FF1 (1) & 5 & 0.39 \\
\hline$X$ & 1.26 & FF2 (1) & 35 & 0.28 \\
\hline $\mathrm{X}$ & 0.6 & FF3 (1) & 65 & 0.36 \\
\hline $\mathrm{X}$ & 0.79 & FF4 (1) & 105 & 0.22 \\
\hline $\mathrm{X}$ & 0.76 & & & \\
\hline $\mathrm{X}$ & 1.02 & \multirow{2}{*}{\multicolumn{3}{|c|}{$\begin{array}{l}\text { Other outcrops of the } \\
\text { Mailly-le-Château reef }\end{array}$}} \\
\hline$X$ & 0.48 & & & \\
\hline$X$ & 0.99 & CL5-1 (3) & - & 0.25 \\
\hline $\mathrm{X}$ & 0.78 & CL5-2 (3) & - & 0.52 \\
\hline$X$ & 0.52 & CL5-3 (3) & - & 0.20 \\
\hline $\mathrm{X}$ & 1.07 & CL5-4 (3) & - & 0.44 \\
\hline $\mathrm{X}$ & 1.15 & ME 1 (6) & 0 & 0.42 \\
\hline$X$ & 0.28 & ME 2 (6) & 50 & 0.32 \\
\hline$X$ & 1.26 & ME 3 (6) & 160 & 0.25 \\
\hline & 1.16 & Fe-h (6) & 0 & 0.36 \\
\hline & 1.27 & Fe-b (6) & 5 & 0.08 \\
\hline \multirow[t]{5}{*}{$\mathrm{X}$} & 2.66 & & & \\
\hline & & \multicolumn{3}{|c|}{$\begin{array}{l}\text { Lateral equivalents of the } \\
\text { Mailly-le-Château reef }\end{array}$} \\
\hline & 1.7 & CRA1 (4) & - & 0.34 \\
\hline & 1.57 & CRA2 (4) & - & 0.22 \\
\hline & 1.14 & CRA3 (4) & - & 0.23 \\
\hline
\end{tabular}

was sampled at the Roche aux Poulets outcrop, situated a little further to the northern side of Merry-sur-Yonne (Fig. 2, point $6 ; N=5$ ). Both the Le Saussois and the Roche aux
Poulets sections belong to the bimammatum Zone of the Late Oxfordian (Menot 1991). The upper part of Le Saussois possibly corresponds to the hypselum Subzone, whereas the 
Table 2 continued

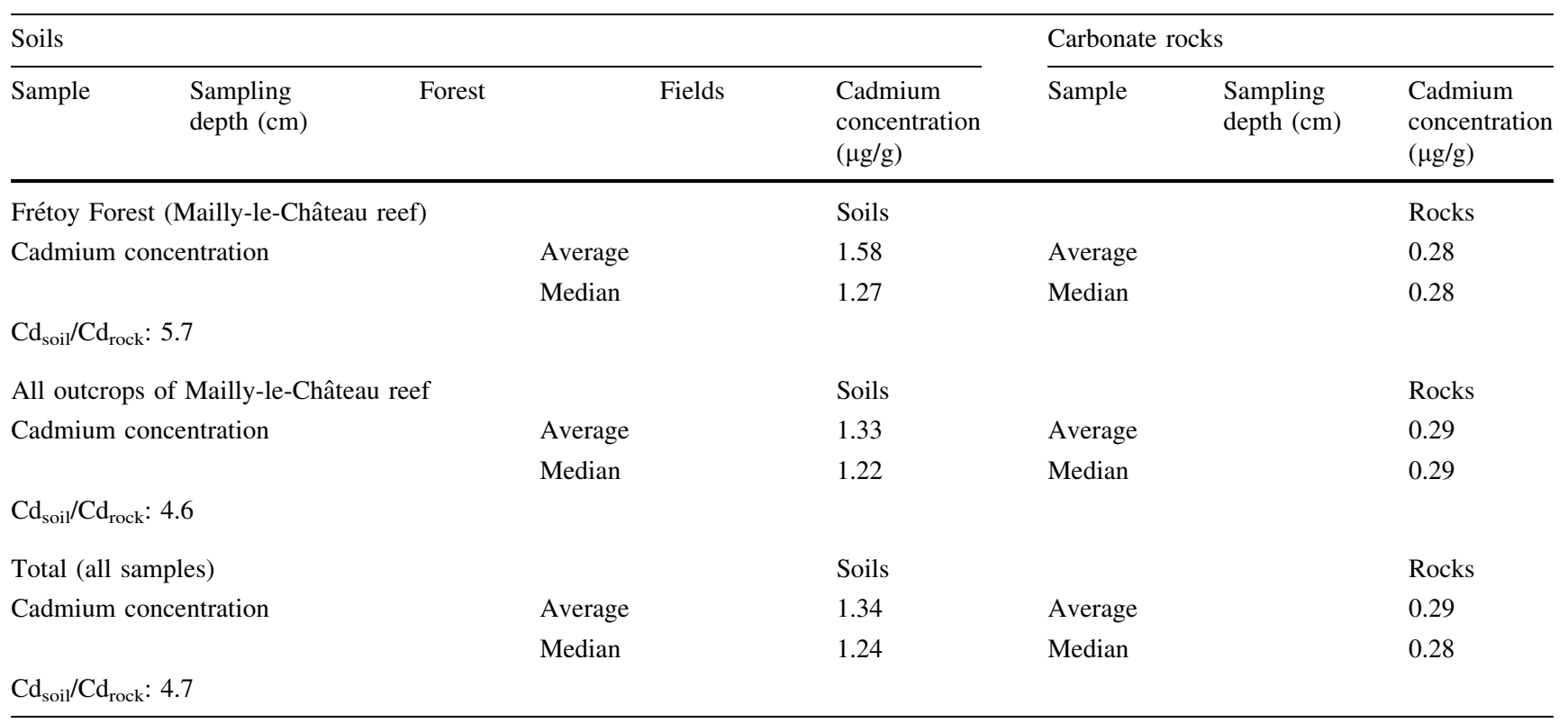

beach facies characterizing the upper part of the Roche aux Poulets succession may be part of the bimammatum Subzone.

\section{Bajocian limestone}

Large fragments of rocks $(N=7)$ were sampled from shallow soils in the Blacy area, which generally present outlying cadmium contents (Fig. 2, point 7). Additionally, the Lucy-le-Bois section, which outcrops in a former quarry (Fig. 2, point 8), was studied to analyze the stratigraphic distribution of cadmium concentrations within the limestone rocks during the Bajocian $(N=19)$. Even if its biostratigraphy is not very well constrained, the Lucy-leBois session is thought to display a condensed limestone succession spanning most of the Bajocian. The first crinoidal limestone layers at the basis of the section overlay marls and marly limestone probably of Toarcian age. Crinoidal limestone, with numerous hardgrounds and perforated surfaces, represent the Early Bajocian sedimentation. In comparison with other Bajocian formations from Burgundy (Thiry-Bastien 2002), the Early to Late Bajocian transition is thought to be marked at Lucy-le-Bois by a hardground surface, rich in ammonites, and separating the crinoidal limestone succession from the essentially micritic overlying layers of Late Bajocian and Bathonian age.

\section{Measurement of cadmium contents}

Two methods were used for the determination of cadmium concentrations in soils:

- Cadmium measurements by inductively coupled plasma-mass spectrometry (ICP-MS) after dissolution by $\mathrm{HF}+\mathrm{HClO}_{4}=$ 'total' concentrations (following the French standard NF X 31-147, AFNOR 1999).

- Cadmium measurements by ICP-MS after dissolution by aqua regia $=$ 'pseudo-total' concentrations (according to the international standard ISO 11466, AFNOR 1999).

Cadmium concentrations obtained by both methods are of the same order of magnitude, and no distinctions have been established between the two populations.

With regard to the rock samples, ICP-MS analyses (ELAN 6100, PerkinElmer) were performed on bulk rock samples, after microwave-assisted (MSL-Ethos plus, Milestone; EPA 3051 procedure) nitric acid digestion (250 $\mathrm{mg}$ of powered sample $+10 \mathrm{ml}$ of concentrated nitric acid, 65\%, suprapur, Merck). The element concentrations of the acid digests were determined using full mass spectra scans (panoramic method). Certified reference materials (CRMs) for trace metals in natural water (NIST 1640) and lake sediments (LKSD-1) were used to estimate the accuracy of the method.

Statistical analysis (soil samples)

The research and definition of anomalously high cadmium concentrations ('outlier' values) in soils was carried on using the exploratory data analysis method (Tukey 1977; McGrath and Loveland 1992):

- on a sample population, an 'interquartile distance' (ID) is arithmetically defined, spreading between the 1 st and 3rd quartiles.

- the 'upper whisker' is defined by adding 1.5 times the ID to the 3rd quartile. 
- all values higher than the upper whisker are considered as 'upper outliers' (referred to in the text as 'outliers'), i.e., anomalously high values for the particular population under consideration.

\section{Results}

Cadmium contents in soils of the Lower Burgundy Plateaus

The region of the Lower Burgundy Plateaus is one of the most anomalous areas in France with regard to cadmium concentrations. When considering data from the ADEME/ INRA program, $32 \%$ of the cadmium concentrations measured in soil samples were 'upper outliers' at the national scale (Table 1), which becomes $48 \%$ when compiling data from both ADEME/INRA and ASPITET surveys.

The cadmium anomalies in this region are related to several specific pedo-geological contexts and the high cadmium concentrations may therefore be related to different processes. The whole region can be divided into seven categories of pedo-geological units (Fig. 2):

- the major alluvial valleys (V);

- the Morvan uplifted block (M), consisting of crystalline and metamorphic rocks, sporadically overlain by silicified and mineralized sedimentary rocks of early Jurassic age (Lias; Caillère et al. 1968);

- the 'Terre Plaine' (TP), which is a large depression comprising the easily erodible Liassic sedimentary rocks (mainly micaceous clays and marls) and the Sinemurian platform;
- the 'Non-Calcareous Residual Cover' (NCRC), which consists of residual soils sometimes reaching more than $1 \mathrm{~m}$ thickness. This category comprises: (1) the 'Terres d'Aubues': reddish iron-rich soils developed in residual clays resulting from the total dissolution of various types of limestone; (2) the 'argiles à chailles' ('clay with cherts'): thick formations containing large amounts of siliceous stones and resulting from the weathering of Callovian cherty limestone by total calcite removal; and (3) ancient (Mio-Pliocene) alluvial sediments;

- shallow soils overlying Jurassic 'hard' limestone: Bajocian, Bathonian, Callovian, Oxfordian, Lower Kimmeridgian, Portlandian (K);

- soils associated with limestone of the large Oxfordian reef complex of Mailly-le-Château (R);

- other soils deriving from Jurassic rocks showing restricted pedogenetic evolution and differentiation.

This study focuses on cadmium outlying values related to soils developed from the Oxfordian reef complex of Mailly-le-Château, as well as from Bajocian limestone. This choice is the result of preliminary studies (e.g., Benitez-Vasquez 1999; Dubois et al. 2002; Prudente et al. 2002; Rambeau 2006), which concluded on generally high cadmium contents for European calcareous rocks of these ages.

Cadmium concentrations in selected soils related to the considered specific bedrocks are presented in Table 2, for soils derived from the weathering of Oxfordian rocks, and Table 3, for those corresponding to Bajocian limestone. For both categories, cadmium contents are generally high and frequently surpass the $0.8 \mu \mathrm{g} \mathrm{g}^{-1}$ whisker value.
Table 3 Cadmium concentrations in Burgundian Bajocian crinoidal limestones and associated soils

\begin{tabular}{|c|c|c|c|c|c|c|c|}
\hline \multicolumn{5}{|l|}{ Soils } & \multicolumn{3}{|c|}{ Carbonate rocks } \\
\hline Sample & $\begin{array}{l}\text { Sampling } \\
\text { depth }(\mathrm{cm})\end{array}$ & Forest & Fields & $\begin{array}{l}\text { Cadmium } \\
\text { concentration } \\
(\mu \mathrm{g} / \mathrm{g})\end{array}$ & Sample & $\begin{array}{l}\text { Sampling } \\
\text { depth }(\mathrm{cm})\end{array}$ & $\begin{array}{l}\text { Cadmium } \\
\text { concentration } \\
(\mu \mathrm{g} / \mathrm{g})\end{array}$ \\
\hline PAJ 1 (9) & $0-15$ & & & 1.37 & & & \\
\hline PAJ 2 (9) & $0-15$ & & & 0.68 & BL 1 (7) & - & 0.23 \\
\hline PAJ 3 (9) & $0-15$ & & & 0.97 & BL 2 (7) & - & 0.04 \\
\hline PA1F1 (7) & $0-4$ & $\mathrm{X}$ & & 1.8 & BL 3 (7) & - & 0.05 \\
\hline PA1F2 (7) & $10-20$ & $X$ & & 2.07 & BLC 1 (7) & - & 0.63 \\
\hline PA1C (7) & $0-20$ & & $\mathrm{X}$ & 1.72 & BLC 2 (7) & - & 0.32 \\
\hline PA2F1 (12) & $0-4$ & $\mathrm{X}$ & & 1.56 & BLC 3 (7) & - & 0.34 \\
\hline PA2F2 (12) & $10-20$ & $\mathrm{X}$ & & 1.81 & BLF-S (7) & - & 0.26 \\
\hline PA2C (12) & $0-20$ & & $\mathrm{X}$ & 1.25 & & & \\
\hline Total & & & & Soils & & & Rocks \\
\hline \multirow{2}{*}{\multicolumn{2}{|c|}{ Cadmium concentration }} & \multicolumn{2}{|c|}{ Average } & 1.47 & Average & & 0.27 \\
\hline & & \multicolumn{2}{|c|}{ Median } & 1.56 & Median & & 0.26 \\
\hline \multicolumn{2}{|c|}{$\mathrm{Cd}_{\text {soil }} / \mathrm{Cd}_{\text {rock }}: 5.5$} & & & & & & \\
\hline
\end{tabular}


However, concentrations are highly variable, even within the same sampling area (e.g., Clamecy measurements, 'Cla', Table 2). This may be related either to specific pedogenic processes or to differences in original cadmium concentrations of the parent rock (Rambeau 2006).

\section{Cadmium contents in parent rocks}

\section{Oxfordian rocks in the immediate vicinity of cadmium-enriched soils}

The Frétoy Forest (Fig. 2, point 1) is characterized by generally high cadmium contents in soils (Table 2). There, limestone rocks were sampled along a transect and analyzed for their cadmium contents. These rocks correspond to the upper part of a fossil reef complex dated as Late Oxfordian (Mégnien et al. 1970, 1971, 1972). The facies is rather homogeneous along the transect and corresponds mostly to very white, almost pure lagoonal micrite without any sedimentary structures. It sometimes contains clasts of corals or bivalves, However, the section situated at the southeastern extremity of the transect is composed of thin limestone beds rich in bioclasts.

Cadmium concentrations determined in these limestone samples vary from 0.12 to $0.55 \mu \mathrm{g} \mathrm{g}^{-1}$ with a mean value and a median value both at $0.28 \mu \mathrm{g} \mathrm{g}^{-1}$ (Table 2). The four samples of corresponding soils taken in this area display cadmium contents of $1.20-2.59 \mu \mathrm{g} \mathrm{g}^{-1}$; values that correspond well to other analyses of soil samples, which developed from the upper part of the reef complex of Mailly-le-Château or its lateral equivalents (Table 2).

Samples of bedrock fragments associated with the soils of the Clamecy fields, characterized by positive outliers in cadmium contents, display comparable cadmium concentrations (Fig. 2, point 3; Table 2). Identical results were obtained on fragments of the Cravant limestone (a micritic, sublithographic limestone that represents the lateral equivalent of the beach facies directly overlapping the uppermost part of the Mailly-le-Château reef complex) inside the cadmium-rich soils of the Précy-le-Sec zone (Fig. 2, point 4; Table 2).

\section{Oxfordian stratigraphic units: Le Saussois section and lateral equivalents}

The reef complex outcropping at Le Saussois is composed of reef buildups, which alternate with lagoonal micrites rich in coral bioclasts (Table 4). With regard to the cadmium contents, the lower part of the section seems to display 'background' cadmium values, i.e., usual values for carbonate rocks (Table 4). In contrast, a distinct shift toward more elevated concentrations is observed in the upper part of the section (probably corresponding to the Late Oxfordian, bimammatum Zone, hypselum Subzone; Menot 1991). Samples showing this positive excursion represent the lateral equivalent of the calcareous bedrock that outcrops in the Frétoy Forest and display similar cadmium contents (Table 2). This increase in cadmium concentrations in the upper part of the reef complex of Mailly-le-Château is also confirmed by the analyses of samples from the outcrop of the Roche aux Poulets (Fig. 2, point 6; Table 4). The base of the Roche aux Poulets section is stratigraphically equivalent to the upper part of the Le Saussois section (Menot 1991; Chevalier et al. 2001). In addition, analyses from the top of the Roche aux Poulets section show that high cadmium contents are also present the beach facies overlapping the uppermost part of the reef complex.

\section{Bajocian limestone rocks}

In Lower Burgundy, soils deriving from a bedrock composed of Bajocian crinoidal, ferrugineous limestone are generally characterized by elevated cadmium contents. Soils of the Blacy area (Fig. 2, point 7) are representative of soils developed from Bajocian crinoidal facies in this area with regard to the cadmium contents, which very often exceed the $0.8 \mu \mathrm{g} \mathrm{g}^{-1}$ whisker value (Fig. 2, points 7, 9, 12; Table 3).

The majority of the bedrock fragments sampled in the Blacy zone displays cadmium values similar to those in the Oxfordian limestone from the Frétoy Forest or other investigated sites in the Lower Burgundy area, with a mean cadmium concentration of $0.27 \mu \mathrm{g} \mathrm{g}^{-1}$ (Table 3). Cadmium measurements performed on the limestone successions of the Lucy-le-Bois section (Table 5) show that the lower part of the section is characterized by a great heterogeneity in cadmium contents, with one extreme value reaching $2.68 \mu \mathrm{g} \mathrm{g}^{-1}$, in contrast to the upper part of the section that displays lower and more homogeneous concentrations.

Ratios between rock and soil concentrations in the Burgundy Plateaus $\left(\mathrm{Cd}_{\text {soil }} / \mathrm{Cd}_{\text {rock }}\right)$

With the assumption of a direct chemical heritage from the bedrock for soils in the investigated areas, concentration ratios $\left(\mathrm{Cd}_{\text {soil }} / \mathrm{Cd}_{\text {rock }}\right)$ between rocks and soils were calculated (Tables 2, 3). $\mathrm{Cd}_{\text {soil }} / \mathrm{Cd}_{\text {rock }}$ ratios represent an estimate on how much (on average) soils would concentrate the cadmium inherited from the bedrock dissolution (Quezada-Hinojosa et al. 2009). The $\mathrm{Cd}_{\text {soil }} / \mathrm{Cd}_{\text {rock }}$ ratios mostly reflect local pedogenic processes (age of the soil and its degree of development, and possible losses of cadmium by lateral and vertical transfers). The main interest of calculating such ratios is to estimate potential cadmium values in soils of a specific area knowing the concentrations in associated bedrocks. 
Table 4 Cadmium concentrations in Oxfordian carbonate rock sections: Le Saussois (5) and La Roche aux Poulets (6)

\begin{tabular}{|c|c|c|c|c|}
\hline Section & Sample & $\begin{array}{l}\text { Sampling } \\
\text { depth }(\mathrm{cm})\end{array}$ & Carbonate facies & $\begin{array}{l}\text { Cadmium } \\
\text { concentration } \\
(\mu \mathrm{g} / \mathrm{g})\end{array}$ \\
\hline Roche aux Poulets A & $\mathrm{Fe}-\mathrm{h}$ & 0 & M. w/fenestraes & 0.36 \\
\hline Roche aux Poulets A & Fe-b & 5 & P. w/oncoids & 0.08 \\
\hline Roche aux Poulets B & ME 1 & 0 & P. w/coral clasts, bivalves, oncoids & 0.42 \\
\hline Roche aux Poulets B & ME 2 & 50 & P. w/oncoids, bivalves, coral clasts & 0.32 \\
\hline Roche aux Poulets B & ME 3 & 160 & P. w/oncoids, bivalves & 0.25 \\
\hline Le Saussois & SA 1 & 0 & M. w/peloids and coral clasts & 0.20 \\
\hline Le Saussois & SA 2 & 160 & W.-P. w/peloids, mictitized clasts, bivalves & 0.46 \\
\hline Le Saussois & $\mathrm{SA} 2^{\mathrm{a}}$ & 160 & & 0.35 \\
\hline Le Saussois & SA 3 & 350 & W.-P. w/coral clasts, gasteropods, peloids & 0.50 \\
\hline Le Saussois & SA 4 & 480 & W.-P. w/coral clasts, gasteropods, peloids, oncoids & 0.16 \\
\hline Le Saussois & $\mathrm{SA} 4^{\mathrm{a}}$ & 480 & & 0.18 \\
\hline Le Saussois & SA 5 & 630 & P. w/coral clasts, peloids, mictitized clasts & 0.18 \\
\hline Le Saussois & SA 6 & 830 & P. w/coral clasts, peloids, mictitized clasts & 0.08 \\
\hline Le Saussois & SA 7 & 1,430 & W. w/coral clasts, other bioclasts & 0 \\
\hline Le Saussois & SA 8 & 1,720 & W.-P. w/coral clasts, bivalves, micritized & 0 \\
\hline Le Saussois & SA $8^{\mathrm{a}}$ & 1,720 & elements and peloids & 0.08 \\
\hline Le Saussois & $\mathrm{SA} 8^{\mathrm{a}}$ & 1,720 & & 0.09 \\
\hline Le Saussois & SA 9 & 1,950 & P.-W. w/oncoids, oolites, intra- and bio-clasts & 0.02 \\
\hline Le Saussois & SA 10 & 2,380 & P.-W. w/coral clasts, oncoids, bivalves & 0 \\
\hline
\end{tabular}

Facies classification following Dunham (1962)

$M$. Mudstone, $W$. Wackestone, $P$. Packstone

$w /$ with

${ }^{a}$ Duplicate

To consider both statistical accuracy (using more values provides a better evaluation) and pedo-geochemical homogeneity (a reduced area produces more realistic results), mean $\mathrm{Cd}_{\text {soil }} / \mathrm{Cd}_{\text {rock }}$ ratios were calculated for different geographical contexts (i.e., as shown in Table 2). In each case, mean values were calculated for soils and rocks, respectively, and the mean $\mathrm{Cd}_{\text {soil }} / \mathrm{Cd}_{\text {rock }}$ ratios were obtained by directly dividing the first value by the second one. Cadmium concentrations measured in the sections of Le Saussois, Roche aux Poulets and Lucy-le-Bois were not taken into account, considering the large stratigraphic scale represented and the associated large variations in cadmium contents. The values obtained vary from 4.6 to 5.7 (Tables 2,3 ) in function of the different sets of samples taken into account.

\section{Discussion}

Cadmium contents of Jurassic limestone in the Lower Burgundy area

Jurassic bedrock, both of Oxfordian and Bajocian age, has been shown to present rather high cadmium contents (average concentrations of 0.29 and $0.27 \mu \mathrm{g} \mathrm{g}^{-1}$, respectively) in the Lower Burgundy area. These values are quite elevated compared to the mean cadmium concentration given for carbonate rocks in literature (0.030 $0.065 \mu \mathrm{g} \mathrm{g}^{-1}$; Tuchschmid 1995; Kabata-Pendias and Pendias 1992; Alloway 1995). Moreover, the limestone successions of Le Saussois/Merry-sur-Yonne (Oxfordian) present a positive shift in cadmium concentrations in the uppermost part of the reef complex (Le Saussois section), which represent the lateral equivalent of the limestone outcropping in the Frétoy Forest, as well as in the overlying beach facies (Merry-sur-Yonne section). Cadmium concentrations obtained for the Lucy-le-Bois stratigraphic section show that limestone rocks of early Bajocian age in the Lower Burgundy area may present rather high cadmium concentrations (up to $2.6 \mu \mathrm{g} \mathrm{g}^{-1}$ ), and that the vertical distribution of cadmium concentrations strongly varies on the scale of a few tens of centimeters. These results are in complete accordance with those obtained by recent studies on cadmium contents of Bajocian and Oxfordian carbonates in western and southern Europe in general (Rambeau 2006). This last study has established that for one or both periods, cadmium contents are highly 
Table 5 Cadmium concentrations for the Bajocian carbonate rock section of Lucy-le Bois (8)

\begin{tabular}{|c|c|c|c|}
\hline Sample & $\begin{array}{l}\text { Sampling } \\
\text { depth }(\mathrm{cm})\end{array}$ & Carbonate facies & $\begin{array}{l}\text { Cadmium concentration } \\
(\mu \mathrm{g} / \mathrm{g})\end{array}$ \\
\hline Lu 17 & 0 & M. w/brachiopods clasts & 0.12 \\
\hline Lu 16 & 40 & M. w/bioturbation, small voids (dissolved bioclasts) & 0.01 \\
\hline Lu 15 & 60 & M. w/thin clay layers intercalated & 0.04 \\
\hline Lu 14 & 85 & M. w/voids, bioclast ghosts & 0 \\
\hline Lu 13 & 140 & M. w/voids, bioclast ghosts & 0 \\
\hline Lu 12 & 195 & M. w/voids, bioclast ghosts & 0 \\
\hline Lu 11 & 215 & M. w/voids, bioclast ghosts & 0 \\
\hline Lu 10 & 315 & P. w/micritized elements, crinoids, ammonites & 0.14 \\
\hline $\mathrm{Lu} 10^{\mathrm{a}}$ & 315 & & 0.10 \\
\hline Lu 9 & 405 & P. w/micritized elements, crinoids & 0 \\
\hline Lu 8 & 450 & W.-P. w/crinoids, micritized elements & 0 \\
\hline Lu 7 & 510 & W.-P. w/crinoids, micritized elements & 0 \\
\hline Lu $6 s$ & 554 & Ferrugineous hardground & 0.11 \\
\hline Lu 6 & 555 & W.-P. w/crinoids, micritized elements & 0.03 \\
\hline Lu 5 & 620 & W.-P. w/crinoids & 0 \\
\hline $\mathrm{Lu} 4$ & 715 & W.-P. w/crinoids & 0.40 \\
\hline Lu 3 & 760 & W. w/crinoids & 0 \\
\hline Lu 2 & 810 & W.-P. w/brachiopods, micritized elements and crinoids & 2.68 \\
\hline Lu 1 & 840 & W.-P. w/crinoids, clay layer & 0 \\
\hline
\end{tabular}

Facies classification following Dunham (1962)

$w /$ with

$M$. Mudstone, $W$. Wackestone, $P$. Packstone

${ }^{a}$ Duplicate

variable, with very high concentrations often limited to layers of a few centimeters thickness.

Limestone rocks in Lower Burgundy represent, therefore, a very likely source for cadmium anomalies in deriving soils. However, the great variability of cadmium contents in limestone must be of some repercussion to the cadmium concentrations displayed in deriving soils.

Possible causes for high cadmium concentrations in sedimentary rocks of the Lower Burgundy area

If a causal link between high cadmium concentration in the bedrock and in deriving soils seems to exist at least in some zones of the Lower Burgundy, the origin of cadmium enrichment in the sedimentary rocks remains unclear. Enrichments due to the mineralization of sedimentary rocks via hydrothermal fluids following major faults have been suspected to play an important role in creating cadmium enrichments in areas directly in contact with the Morvan ancient crystalline massif. This concerns in particular rocks of the lower Lias, Sinemurian and Hettangian age (Caillère et al. 1968; Baize and Chrétien 1994). The zones studied here are located at a respectable distance from the border with the crystalline massif and consists of
Bajocian and Oxfordian bedrocks, which are only marginally affected by faulting (cf geological maps of the area: Mégnien et al. 1971, 1972). It seems therefore probable that, if fluids circulating along tectonic fractures induced the creation of $\mathrm{Cd}$ enrichments within certain types of rocks in Lower Burgundy, this mechanism is not responsible for the high concentrations discovered in Bajocian and Oxfordian limestone.

The second possibility is that specific stratigraphic layers within the Jurassic, and more particularly within the Bajocian and the Oxfordian, are naturally Cd enriched, and developed these high concentrations either during sedimentation or early diagenesis. This assumption is sustained by a series of arguments. For example, the fact that lateral equivalents of the same formation display similar Cd contents over $\sim 10 \mathrm{~km}$ (e.g., Frétoy Forest and Le Saussois) speaks in favor of this hypothesis. Another point to consider is the results of a recent study focused on $\mathrm{Cd}$ contents of Jurassic carbonates (and more particularly Bajocian and Oxfordian) in western and southern Europe (Rambeau 2006). This study has highlighted a tendency of carbonate rocks to be enriched (by comparison to their older or younger counterparts) when belonging to selected time periods of the Jurassic. However, the 
determination of the causes and mechanisms that led to high cadmium concentrations in specific Jurassic carbonates all over Europe is still at its beginning. More studies are necessary to separate long-term, regional variations in the cadmium cycle and more local phenomena, such as processes of enrichment that may have happened during the sedimentation or the early diagenesis, or the influence of post-depositional events such as faulting and fluid circulation.

\section{Role of specific carbonate facies}

The conclusion of previous studies is that in Burgundy, biogenic limestones (reef or bioclastic deposits) are often anomalous with regard to cadmium concentrations (Baize 1997; Baize et al. 1999). These authors also concluded that, however, not all bedrocks consisting of biogenic limestones are associated with soils rich in cadmium (Baize et al. 1999). In addition, in the Jura area, most of the calcareous rocks showing unexpectedly high cadmium concentrations present an oolitic/oncoidal facies, whereas bioclastic rocks are generally less rich in cadmium (Benitez-Vasquez 1999; Dubois et al. 2002). In this study, cadmium concentrations appear to be quite independent of the specific rock facies, as similar kinds of limestone may present very different cadmium concentrations (e.g., at Le Saussois section, Table 4).

\section{Ratios between rock and soil concentrations}

in the Burgundy Plateaus $\left(\mathrm{Cd}_{\text {soil }} / \mathrm{Cd}_{\text {rock }}\right)$

Soils in Lower Burgundy are all autochthonous and receive negligible cadmium from anthropogenic activities. All the cadmium concentrated in the soils should therefore be a direct heritage from the parent bedrock chemistry. The wide range of concentrations obtained for both the Jurassic limestone and the deriving soils for the Lower Burgundy, however, renders difficult the calculation of ratios that would accurately reflect concentration processes between parent rocks and overlying soils.

Considering that cadmium concentrations sometimes varies stratigraphically by a factor of ten in a few decimeters (e.g., Lucy-le-Bois section, Table 5), and that the layers from which soils have developed are no longer present, it is quite difficult to calculate a realistic $\mathrm{Cd}_{\text {soil }} /$ $\mathrm{Cd}_{\text {rock }}$ by measuring cadmium contents in the soil and in the directly underlying rock. One possibility is to take into account all values corresponding to a defined area, for both soils and rocks. Another problem immediately arises, with the frequent differences in the locations of rocks and soils sampling. The difficulty is thus to balance between statistical accuracy and pedo-geochemical homogeneity, and this is well expressed by the various mean $\mathrm{Cd}_{\text {soil }} / \mathrm{Cd}_{\text {rock }}$ obtained for different geographical settings (from 4.6 to 5.7; Tables 2, 3).

Data sets for the Oxfordian from the Frétoy Forest and for the Bajocian from the Blacy area provide the most realistic calculations: they both contain soils from a restricted area and fragments of bedrock sampled in the immediate vicinity of soils showing high cadmium contents. The very good accordance between the two mean $\mathrm{Cd}_{\text {soil }} / \mathrm{Cd}_{\text {rock }}$ obtained (5.7, Table 2, and 5.5, Table 3, respectively) plays in favor of realistic values despite the rather low number of samples available in both cases. It may also indicate that mechanisms of concentration do not vary as a function of specific rock age or facies.

Although the $\mathrm{Cd}_{\text {soil }} / \mathrm{Cd}_{\text {rock }}$ calculated for soils developed from Oxfordian limestone are based on more measurements, they are skewed by heterogeneities in the location of rock and soil samplings and/or in soil types. Inclusion of soils developed from non-anomalous rocks and/or of 'normal' limestone bedrocks in the calculations may explain the slightly lower values obtained for the mean $\mathrm{Cd}_{\text {soil }} / \mathrm{Cd}_{\text {rock }}$ corresponding to larger areas in Lower Burgundy ('all outcrops of the Mailly-le-Château reef': 4.6 and 'total': 4.7; Table 2).

All these ratios, independent of the way they are calculated, are relatively high, which emphasizes the capacity of Lower Burgundy soils to retain and accumulate the cadmium already present in considerable amounts in certain of associated bedrocks. This is important for the environmental monitoring of soils in this area, which may present elevated pedo-geological backgrounds with regard to cadmium, independently of any human-induced contamination.

\section{Mechanism of cadmium concentration in soils}

In soils associated with limestone rocks presenting high cadmium concentrations, cadmium has been suggested to concentrate by progressive carbonate dissolution and in situ adsorption on clay minerals and iron and manganese oxy-hydroxides (Baize et al. 1999; Benitez-Vasquez 1999; Prudente et al. 2002). In Burgundy, climatic conditions favor the dissolution of all calcareous materials. In the case of 'hard' limestone bedrocks, which are relatively resistant to erosion, the major soil-forming process is calcium carbonate dissolution, with silicate residues (essentially clay particles) progressively accumulating in situ (Baize 1972, 1991). The thickening of the clayey soil mantle through time induces a progressive acidification, which accentuates the dissolution of the underlying limestones (NCRC soils, Fig. 2).

Other processes should, however, be examined to explain the present-day cadmium distribution in soils. In the case of Lower Burgundy, these consist of vertical lixiviation and lateral transfer. On one hand, the lixiviation of 
a certain amount of the cadmium initially present in soils, into the karstic network is highly probable, particularly in the case of the more acidic soils. Such a process will result in a cadmium impoverishment within the soil. On the other hand, lateral transfer is not considered to exert a major influence on the evolution of cadmium concentrations in these soils, which are generally located on flat land or gentle slopes.

The summary of heritage from the geochemical background (itself subjected to high fluctuations related to the extreme variability of the rock chemistry and subsequent soil evolution) therefore produces a large range of cadmium concentrations in soils.

\section{Conclusions}

The cadmium analyses performed on Oxfordian and Bajocian limestone rocks and deriving soils in Lower Burgundy have highlighted the following points:

- Bajocian and Oxfordian limestone rocks in Lower Burgundy display a wide range of cadmium concentrations, which is in accordance with the variability of cadmium contents observed in deriving soils.

- Limestone fragments sampled within cadmium-rich soils present cadmium concentrations higher than those commonly found in calcareous rocks.

- The analyzed limestone sections show stratigraphic intervals in which cadmium contents are unusually high for limestone, in general, but similar to several layers of Bajocian and Oxfordian age discovered in carbonate rocks in western and southern Europe (Rambeau 2006). These layers stratigraphically correspond to the parent rocks of soils presenting anomalously high cadmium contents.

These results confirm that in Lower Burgundy, the Jurassic limestone bedrocks, where they are themselves cadmium-enriched, are an obvious source of cadmium for the soils that derive from them. This is the case in particular for soils derived from the Mailly-la-Ville reef complex of Oxfordian age, and from the Bajocian crinoidal limestone outcropping at Lucy-le-Bois. High cadmium concentrations have been shown to exist in specific stratigraphic layers of both Bajocian and Oxfordian limestone rocks, and the weathering of these have led to a progressive concentration of cadmium in corresponding soils. Cadmium contents in these limestone rocks are independent of their specific facies, and rocks of comparable facies may show highly different cadmium concentrations (e.g., at Le Saussois section).

Mean $\mathrm{Cd}_{\text {soil }} / \mathrm{Cd}_{\text {rock }}$ ratios calculated range from 4.6 to 5.7, the most realistic values being around 5.5-5.7. However, the calculation of such ratios is delicate, considering the wide variability of rock chemistry with regard to cadmium, and the possibilities of remobilization and vertical transfer of this element after bedrock dissolution.

The geochemical investigations conducted in Lower Burgundy thus confirm the influence of a Cd-enriched Jurassic bedrock on the composition of associated soils. These observations are in complete agreement with previous results obtained from the studies on Bajocian and Oxfordian carbonates and deriving soils in the Jura area (e.g., Liebig 1996; Benitez-Vasquez 1999; Prudente 1999; Baize and Sterckeman 2001; Dubois et al. 2002; Prudente et al. 2002; Quezada-Hinojosa et al. 2009). High variability in cadmium contents for limestone of Bajocian and Oxfordian age in Lower Burgundy may explain the wide range of cadmium concentrations, and their spatial variability, obtained for the corresponding soils. The high ratios calculated between the respective concentrations of bedrocks and associated soils highlight the necessity of monitoring soil cadmium contents, in areas where $\mathrm{Cd}$ enriched rocks are susceptible to outcrop.

Acknowledgments The authors would like to thank warmly JeanClaude Menot for field assistance and advice, and the ADEME/INRA and "ASPITET" programs for data provision. The authors acknowledge financial support from the Swiss National Science Foundation (projects no. 21-65183.01, 200020-101718/1) and from the National Centre of Competence in Research ('Plant Survival'). The authors wish to extend their thanks to Raúl Quezada-Hinojosa, Natalia Efimenko, Eric Verrecchia, Jean-Michel Gobat, Claire Le Bayon, Olivier Jacquat, Séverine Vancolen, and Tiffany Monnier for their help and advice during the completion of the projects.

\section{References}

Arrêté du 8 janvier 1998 fixant les prescriptions techniques applicables aux épandages de boues sur les sols agricoles en application du décret No. 97.1133 du 8 Décembre 1997. Journal Officiel du 31 Janvier 1998

AFNOR (1999) Qualité des sols. Recueil de normes françaises, vol 2, 4th edn. La Défense, Paris

Alloway BJ (1995) Cadmium. In: Alloway BJ (ed) Heavy metals in soils, 2nd edn. Blackie Academic and Professional, London, pp 122-147

Atteia O, Dubois JP, Webster R (1994) Geostatistical analysis of soil contamination in the Swiss Jura. Environ Pollut 86:315-327

Atteia O, Thélin Ph, Pleifer HR, Dubois JP, Hunziker JC (1995) A search for the origin of cadmium in the soil of the Swiss Jura. Geoderma 68:149-172

Baize D (1972) Les sols développés dans la couverture des plateaux jurassiques de Bourgogne. Pédogenèse et origine. Science du Sol $1: 37-43$

Baize D (1991) Sols et formations superficielles sur calcaires durs dans le sud-est du Bassin Parisien. Première synthèse. Science du Sol 29:265-287

Baize D (1993) Petites régions naturelles et paysages pédologiques de l'Yonne. Notice et carte à 1/200 000. Unité de Science du Sol, INRA Orléans

Baize D (1996) Carte des sols de l'Yonne. Feuille Vermenton. Notice et carte à 1/50.000. Conseil Général de l'Yonne et INRA Orléans 
Baize D (1997) Teneurs totales en éléments traces métalliques dans les sols (France). Références et stratégies d'interprétation. INRA, Paris

Baize D, Chrétien J (1994) Les couvertures pédologiques de la plateforme sinémurienne en Bourgogne. Particularités morphologiques et pédogéochimiques. Etude et Gestion des Sols 1(2):7-27

Baize D, Paquereau H (1997) Teneurs totales en éléments traces dans les sols agricoles de Seine-et-Marne. Etude et Gestion des Sols 4(2):77-94

Baize D, Roddier S (2002) Approche typologique d'une cartographie pédogéochimique. Exemple de l'Avallonnais. In: Baize D, Tercé M (eds) Les éléments traces métalliques dans les sols. Approches fonctionnelles et spatiales. INRA, Paris, pp 123-134

Baize D, Sterckeman T (2001) Of the necessity of knowledge of the natural pedogeochemical background content in the evaluation of the contamination of soils by trace elements. Sci Total Environ 264:127-139

Baize D, Deslais W, Gaiffe M (1999) Anomalies naturelles en cadmium dans les sols de France. Etude et Gestion des Sols 6:85-104

Baize D, Saby N, Deslais W, Bispo A, Feix I (2006) Analyses totales et pseudo-totales d'éléments en traces dans les sols-Principaux résultats et enseignements d'une collecte nationale. Etude et Gestion des Sols 2:181-200

Benitez-Vasquez N (1999) Cadmium speciation and phyto-availability in soils of the Swiss Jura: hypothesis about its dynamic. $\mathrm{PhD}$ dissertation, Ecole Polytechnique Fédérale de Lausanne

Caillère S, Kraut F, Horon O, Lefavrais-Raymond A, Rouire J (1968) Carte géologique de la France (1/50 000), feuille Quarré-lesTombes (467), et notice explicative. Bureau de recherches géologiques et minières (BRGM), Orléans

Chevalier F, Garcia JP, Quesne D, Guiraud M, Menot JC (2001) Corrélations et interprétations génétiques dans les formations récifales oxfordiennes de la haute vallée de l'Yonne (sud-est du bassin de Paris, France). Bull Soc Géol France 172(1):69-84

Colinet G, Laroche J, Etienne M, Lacroix D, Bock L (2004) Intérêt d'une stratification pédologique pour la constitution de référentiels régionaux sur les teneurs en éléments traces métalliques dans les sols de Wallonie. Biotechnol Agron Soc Environ 8(2):83-94

Dubois JP, Benitez N, Liebig T, Baudraz M, Okopnik F (2002) Le cadmium dans les sols du haut Jura suisse. In: Baize D, Tercé M (eds) Les éléments traces métalliques dans les sols. Approches fonctionnelles et spatiales. INRA, Paris, pp 33-52

Dunham RJ (1962) Classification of carbonate rocks according to depositional texture. In: Ham WE (ed) Classification of carbonate rocks. Memoir 1. American Association of Petroleum Geologists, Tulsa, pp 108-121

Décret No. 97.1133 du 8 Décembre (1997) relatif à l'épandage des boues issues du traitement des eaux usées. Journal Officiel de 10 Décembre 1997
Kabata-Pendias A, Pendias H (1992) Trace elements in soils and plants, 2nd edn. CRC Press, Boca Raton

Liebig T (1996) Untersuchungen zu den Bindungsformen und der Bioverfügbarkeit von Cadmium in den Böden des Schweizer Jura. $\mathrm{PhD}$ dissertation, University of Berlin

McGrath SP, Loveland PJ (1992) The soil geochemical atlas of England and Wales. Blackie Academic and Professional, Glasgow

Mégnien C, Mégnien F, Turland M (1970) Le récif oxfordien de l'Yonne et son emplacement sur la feuille Vermenton (1/50 000). Bull BRGM (2nd series) I(3):83-115

Mégnien C, Mégnien F, Turland M, Villalard P (1971) Carte géologique de la France au 1/50 000, feuille Vermenton. BRGM, XXVII (21)

Mégnien C, Mégnien F, Turland M, Villalard P (1972) Carte géologique de la France au 1/50 000, feuille Courson-lesCarrières. BRGM, XXVII (21)

Menot JC (1991) Formations d'âge Oxfordien dans la vallée de l'Yonne. In: Floquet M, Javaux C, Menot JC, Purser BH (eds) Sédimentation, diagenèse et séquences de dépôt dans les séries carbonatées de plate-forme d'âge bathonien à oxfordien en Bourgogne. Livret-Guide A.S.F., Paris, pp 125-167

OSol (1998) Ordonnance du 1er juillet 1998 sur les atteintes portées aux sols. Swiss Federal Council, RS 814.12, Bern

Palumbo B, Angelone M, Bellanca A, Dazzi C, Hauser S, Neri R, Wilson J (2000) Influence of inheritance and pedogenesis on heavy metal distribution in soils of Sicily, Italy. Geoderma 95:247-266

Prudente D (1999) Distribution des teneurs naturelles en cadmium dans les sols de la forêt communale des Fourgs (Doubs, France). DES Sciences naturelles de l'environnement. Dissertation, Universities of Geneva and Lausanne

Prudente D, Baize D, Dubois JP (2002) Le cadmium naturel dans une forêt du haut Jura français. In: Baize D, Tercé M (eds) Les éléments traces métalliques dans les sols. Approches fonctionnelles et spatiales. INRA, Paris, pp 53-70

Quezada-Hinojosa R, Matera V, Adatte T, Rambeau C, Föllmi KB (2009) Cadmium distribution in soils covering Jurassic oolitic limestone with high $\mathrm{Cd}$ contents in the Swiss Jura. Geoderma 150:287-301

Rambeau C (2006) Cadmium anomalies in Jurassic carbonates (Bajocian, Oxfordian) in western and southern Europe. PhD Dissertation, University of Neuchâtel

Thiry-Bastien (2002) Stratigraphie séquentielle des calcaires bajociens de l'Est de la France (Jura, Bassin de Paris). PhD Dissertation, Université Claude Bernard, Lyon 1

Tuchschmid M (1995) Quantifizierung und Regionalisierung von Schwermetallen und Fluorgehalten bodenbildender Gesteine der Schweiz. Umwelt-Materialien 32. BUWAL, Berne

Tukey JW (1977) Exploratory data analysis. Addison Wesley, Reading 